Article received on 12 September 2013

Article accepted on 30 September 2013

UDC: 781.7(470)"1950/1970"

\title{
MICROTONAL RUSSIA: 1950-1970s MYTHS AND REALITIES*
}

\section{Lidia Ader}

St. Petersburg, Russia

The Russian history of new music in the $20^{\text {th }}$ century could be called 'impulsive'. There were powerful stimuli, given by Western music which Russian composers did or did not, however, respond to. In my article, I am going to discuss some mechanisms of the historical development of microtonal music in Russia 1950-1970s in comparison to what was produced at the beginning of the century.

Musicological studies of Russian microtonal music have never become a separate topic of research and have never appeared as a component of the whole microtonal school. In S. Schneider's most important book, Mikrotöne in der Musik des 20. Jahrhunderts ${ }^{1}$, the overview ends more or less with the 1950s. Most of the existing printed information given by leading musicologists is based on the research of the early 1920s avant-garde (Detlef Gojowy, Larry Sitsky) and does not cover the later period; so, it needs to be rewritten and reviewed. There was never even an attempt to describe Russian microtonal music,

\footnotetext{
* Author contact information: lidia.ader@artparking.org

This research is realised with a financial support of Russian Foundation for Humanities (project number 13-04-00427). I would like to express my deepest gratitude to Prof Liudmila Kovnatskaya for discussing this article and Dr Pauline Fairclough for the help with correcting English translation.

1 Sigrun Schneider, Mikrotöne in der Musik des 20. Jahrhunderts, Bonn, Verlag für systematische Musikwissenschaft GmbH, 1975, 317 S.
} 
except for one very interesting article entitled "Micro and consequences" ${ }^{2}$ by Yuri Kholopov, but this will be reviewed later.

Let us go deeper into all the processes surrounding microtonal music in Russia.

\section{Russian musical avant-garde}

It is customary to refer to 1959 as the beginning of the second wave of the avant-garde of (or, as it is often called 'Russian musical avant-garde after the World War II'). Andrey Volkonsky, who returned to Russia from emigration in Switzerland, started composing in twelve-note technique, having armed himself with a knowledge of all the newest trends, and a knowledge of the actual, modern composers' works. His Mirror Suite (1959) and Lamentations of Schchaza (1960) partially lifted the veil over Russian musical life, after 30 years, and became sui generis the 'green corridor' to European minds. Volkonsky organized a composers' group, which was headed by Edison Denisov, Sofia Gubaidulina, Alfred Schnittke, though Volkonsky always seemed to be "at home among strangers, a stranger among his own" 3 - he was discharged from the conservatoire; his works, after one-time performances, were commissioned only for films; and the most avant-garde compositions were soon forgotten.

By that time, twelve-tone technique in the West had a forty-year history. Having gone through various stages of development, implementation and extension, frankly speaking, by the 1960s it was outdated. Relying on his creative experiences, Andrey Volkonsky summarized it in 1996: "Dodecaphony, a legitimate child of equal temperament, apparently exhausted itself". ${ }^{4}$ The Russian avant-garde composers prolonged its life, revealed its viable elements, while trying to interpret and combine it with the new principles of composition.

The way of learning dodecaphony and serialism in the circumstances of Soviet reality was a priori clandestine. Musicians truly conspired to listen to Schoenberg, Berg, Webern, Stravinsky, Boulez and Stockhausen. They shared scores by photocopying. 'Forbidden fruit' was much more tempting than their own Soviet past, to which they were blind. This was associated with the symbols of the political situation, Stalinism and government actions such as the old

2 Yuri Kholopov, 'Mikro i posledstviya' [Micro and consequences], in: L. Diachkova (ed.) Muzykalnoe obrazovanie v kontekste kulturi: Voprosy teorii, istorii i metodologii. Materialy nauchno-proktichestoj konferentsii 27 - 29 oktyabrya 1998 goda. Moskva, 2000, 27-38. I am very grateful to Olesya Bobrik who helped me to find this rare edition.

3 This quotation is the title of a 1974 Soviet film directed by Nikita Mikhalkov.

4 Andrey Volkonsky, Osnovy temperatsii (Basis of temperament), Moscow, Kompozitor, 2003 (1996), 41. 
fights against so-called formalism. They included the 1910s and the 1920s in the category of the Soviet past, the years of futurism/avant-gardism, usually called 'the first wave of avant-garde' in Russia.

It was this 'formalism' in 1929 that cancelled out all attempts by the Russian revolutionaries to turn the course of history, to speed up the development of art and to discover the appropriate answer to the legitimate product of equal temperament - dodecaphony, most notably the elaboration of non-tempered systems. Further on, I shall focus my attention on the different attempts at rediscovering the principles of temperament in the Russia of the 1960s and divining the sound zone. Moreover, I would like to conclude by formulating the true position of the ideas of these composers during the 1960s, in the context of the broader strategies of art developments.

\section{Approaching microtonality}

What is the method of composers who use microtonal music? In applying Roland Barthes's theory to it, ${ }^{5}$ equal temperament constructed a new musical organism, an abstract set of constituent elements during the 300 years of its existence. However, two generations of composers had different intentions with this 'organism'. One group found freedom and discovered new sound perspectives, trying to create new models for the organization of musical texture. Having favoured the degeneration of equality in temperament, they appealed to pure intonation in different ways. Their idea was to organize a new model, because pure intonation is a completely different paradigm, constructed upon other physical laws. In contrast to that, the other group took the system of equal temperament as an example, trying to widen and fragment it, preserving the laws of musical texture.

In 1923, at the St Petersburg Conservatory, the Circle of quarter-tone music was founded. ${ }^{6}$ Its members were conservatory students and leading microtonal composers of Europe, who became its associate members (Alois Hába, William Möllendorf, Jörg Mager, Richard Stein and Ivan Wyschnegradsky). The research potential of the Circle was supported by its founder Georgy RimskyKorsakov (1901-1965), the grandson of the great Russian composer Nikolai Rimsky-Korsakov. In 1925, he published an article where he attempted to formulate the basis of the quarter-tone system and explain new principles of com-

\footnotetext{
5 Theoretical conception of the ship Argo is introduced in the book: Roland Barthes by Roland Barthes. Translated by Richard Howard. Berkeley, Los Angeles, University of California Press, 1994 (1977).

${ }^{6}$ History of this circle is described in: Lidia Ader, 'Microtonal storm and stress: Georgy Rimsky-Korsakov and quarter-tone music in 1920s Soviet Russia’, in: Tempo, 2009 (63), 27-44.
} 

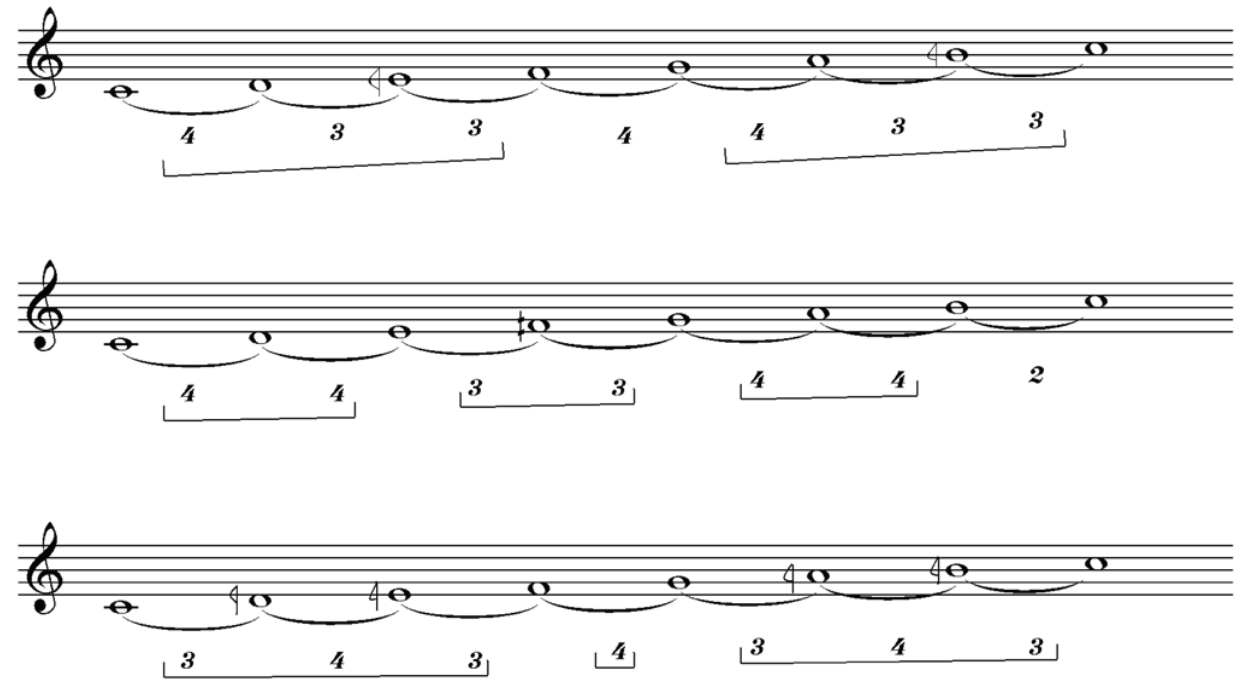

position technique. ${ }^{7}$ According to his theory, the new scale of non-tempered sounds had to become the base for forming new modes: ioniodorian (Ex. 1a), ioniolydian (Ex. 1b) and ioniophrygian (Ex. 1c).

He divided each of them into segments, trying to discover their symmetrical structure (I would like to stress, that this was 20 years before Messiaen wrote his Technique de mon langage musical).

Undoubtedly, Georgy Rimsky-Korsakov did his research work within the context of the theory of modal rhythm, proposed in the 1920-1930s by Boleslav Yavorsky, a theoretician, pianist and author of treatises on the theory and history of music. ${ }^{8}$ He postulated the tritone as the central link of a system, the primary blend of steadiness and unsteadiness ("united symmetrical system" as he called it). In the projection of Yavorsky's base, cores were created of double, triple and manifold symmetry. Both theories - G. Rimsky-Korsakov's and Yavorsky's - were handed down by the successors of the first avant-garde wave. Even in spite of the highly theoretical nature of their early works and their sketchy character, their intentions were aimed at the Second Viennese School.

7 Georgy Rimsky-Korsakov, 'Obosnovanie chetvertitonovoy muzykalnoy sistemy', in: De musica: Vremennik razryada istorii i teorii muzyki. Leningrad, 1925, 52-78.

8 Boleslav Yavorsky, Stroenie muzykalnoi rechi, Moscow, 1908; Sergei Protopopov, Elementy postroeniya muzykalnoj rechi, Moscow, 1930. 
The fate of microtonal music in Russia is typical. The Circle of quartertone music collapsed in 1929. This was partly due to human factors: by that time, the enthusiasm among the Circle's members - former students of the Leningrad Conservatory - had evaporated. However, this was not only because of moving to the film industry (with the birth of sound movies, Nikolay Malakhovsky, Alexander Kenel', Dmitry Shostakovich and Georgy Rimsky-Korsakov himself started writing soundtrack music).

All radical and innovative things that were previously fashionable were now on 'the Procrustean bed' and Lunacharsky's declaration from 1926 - 'The adoption of the quarter-tone system is one of the major phenomena in the formal development of our music. However large the pool of musical works oriented in a different way may be, we will witness the progress of quarter-tone music' 9 - was now out of date and was replaced by that of the agitprop departments, which had a quite different notion of what accessible music would be. One of the Circle's members, Maria Ozhigova, remembered that 'after one concert (evidently in 1925) the newspaper Leningradskaya Pravda published an article about "militant formalism" which sealed the group fate'. ${ }^{10}$

Along with this 'quarter-tone company friendship' the whole period of the flourishing of microtonal music in Russia perished. Yet it had already had a 20-year history if we take the year 1909 as the beginning, when the pamphlet Unrestricted music by Nikolay Kulbin appeared in print. ${ }^{11}$ There, for the first time Kulbin established the problem of the primitiveness of equal temperament. In 1913-1915, Artur Lourie and Mikhail Matushin favoured the spreading of this idea among the artistic and musical masses. Nevertheless, an eight-year gap followed, when musicians timidly tried to adapt their often Utopian ideas to reality. In 1918, Matushin constructed a quarter-tone violin ${ }^{12}$, and two years earlier Ivan Wyschnegradsky suggested a project of a quarter-tone piano. Concert activities in Moscow and Leningrad also became more intensive in the 1920s, generally thanks to the Circle of quarter-tone music.

\footnotetext{
9 Anatolij Lunacharsky, 'Odin iz sdvigov v isskusstvovedenii' (One of the upheavals in art) in: Vestnik kommunisticheskoy Academii, 1926, Vol. XV, 90.

10 M. P. Ozhigova, 'Mitya, Dmitri Dmitrievich' in: A. Selitsky (ed.), Muzykalnaya pedagogika v ideyakh i litsakh: sbornik statey k 25-letiu konservatorii, Rostov on Don, 1992, $85-86$

11 Nikolay Kulbin, Svobodnaya muzyka. Primenenie novoy teorii hudozhestvennogo tvorchestva k muzyke. Sankt-Peterburg, 1909, 7 p.

12 Matushin presented this instrument at the Research department of the Museum of fine arts in 1924. Nowadays this instrument is in the collection of the St Petersburg State Museum of Theatre and Music.
} 
Thus, 1929 became the turning point in the history of Russian microtonal music. The longstanding intense correspondence between G. Rimsky-Korsakov and Wyschnegradsky, where they exchanged their ideas, works and discussed the most topical questions of contemporary music, had stopped by that time. ${ }^{13}$ Gradually, theoretical work also died out: Georgy Rimsky-Korsakov switched to lighting-electrical-musical experiences, ${ }^{14}$ which were nevertheless banned during the hasty 'prophylactic' actions of the Soviet government from 1930-1933, related to closing down the amateur circles. That is why the self-destruction of experimental film studios was quite a better choice than surrendering to compulsory government methods. It is worth pointing out that the government put a veto on politically unreliable contemporary trends, among them - on microtonal music. The results of that decision for Russian music were destructive.

\section{Resistance to microtonal memory}

Symptomatically, the idea of the elaboration of a new language of music and new sound world haunted the representatives of the Russian avant-garde (1920s and 1960s), the only difference being that the degree of radicalism in the first avant-garde wave was undoubtedly higher. It is possible that the resistance to the 'genre memory' during the second avant-garde was due to the quests for a compromise between the method and its artistic value.

As composers sensed the approach of Khrushchev's 'Thaw' in spite of drawing attention to the achievements of the first Russian avant-garde wave and its previously accumulated experience, the 1960s Russian avant-garde ignored the surviving guardians of the Russian tradition, and headed straight for Pierre Boulez, Karlheinz Stockhausen, Luigi Nono and Luciano Berio. In connection with this, the young Soviet radicals had to master complete techniques as fast as they possibly could.

The microtonal idea existed only as a part of experiments. There were no composers in Russia at that time who would develop it consistently. The work of experimental studios (mainly at the Moscow Conservatory) was kept hidden from listeners, and was rather marginal and interesting only to selected composers. Instead of being the result of intelligent and systematic usage, microchromatism employed in early compositions was there for the sake of the idea, for witticism and, presumably, as an attribute of the time. Composers used it for colouristic purposes, often Oriental.

\footnotetext{
13 This correspondence is now divided in two parts: one is in Russian National Library (St Petersburg) and the other is in Paul Sacher Foundation (Basel).

${ }^{14}$ Georgy Rimsky-Korsakov, Rasshifrovka svetovoy stroke Skryabinskogo 'Prometheya', in: De musica: Vremennik razryada istorii i teorii muzyki. Leningrad, 1926, 2, 94-102.
} 
The only person who tried to classify the principles of using microtones in composers' (specifically Russian) works, was Yuri Kholopov. ${ }^{15} \mathrm{He}$ briefly introduced his own vision of micro-regulations:

- first of all he specified a group of 'intermediary' microtones - those in between the 'diatonic' steps - as well as progressing and auxiliary ones;

- microchromatic counterpoint where lines interlace;

- he noted the new possibilities of traditional polyphonic methods. Particularly, that it was possible to create an intervallic compression and the expansion of a theme; he mentioned the 'metabole of origin' (for example, the transition from chromatism to microchromatism and back);

- microtones in harmony can form a cluster of 3 to 12 to 25 tones;

- a constantly moving multi-voice mass consisting of microchromes. This was employed chiefly in slow and condensed lyrical expression.

- Thus, we see an attempt to summarize the numerous implications of microtones. It has to be admitted that these conditions are not equal and have no common denominator. In order to find it, let us have a look at the purpose of using microtones in the works written in 1950-1970s.

- The search for the destruction of integrity in the 20th century can be divided into two categories, which differ in the type of material used. On the one hand there are experiments, in which the division is a system element, base of work, method or principle of organization. These are, in my opinion, a basic function of division. On the other hand, the divided elements are used for the extremely accurate fixation of a text, they exist in art indirectly. They might be called the application tools of division.

- Within the basic functions one can trace several methods used more often than the others: coloristic, systematic and computational ones.

\section{Coloristic method}

Microtones are generally used for:

- the creation of effects (as patterns): Slonimsky in his Concerto-buff employs the quarter-tone cluster, Denisov's Cello concert begins with a microtonal cluster run;

- intensification: in works for strings (Schnittke's Concerto grosso № 2; Slonimsky's Sonata for violoncello) microtonal elements appear as auxiliary or progressing tones with the aim of stressing and intensifying the dramatic potential of pieces.

${ }_{15}$ Yuri Kholopov, op. cit., 31-4. 
Example 2. - Sergey Slonimsky, Three pieces for violoncello solo.

No. 2: Chromatic chant
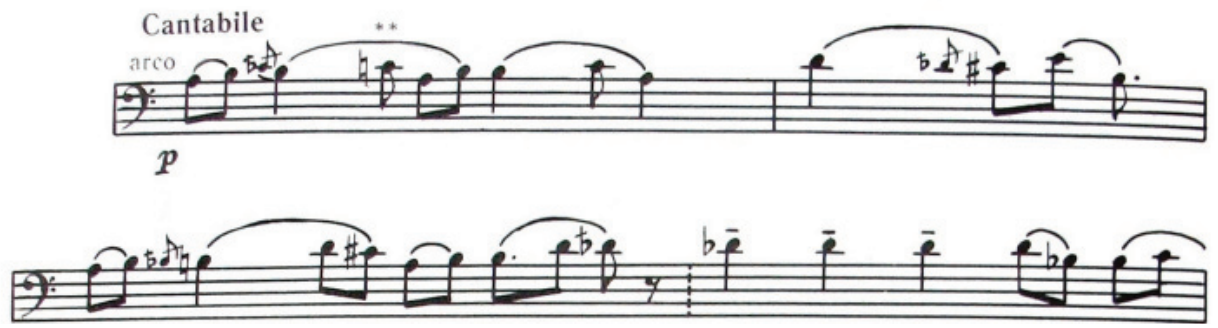

Three pieces for violoncello solo, constructed on a simple melodic core, unfolds gradually, starting from a small motive. This cochlear structure unwinds with deepening tone structure. The composer methodically returns to the same intonation within a whole tone, using the interval as thoroughly as possible.

- sound imitation, or national characteristics, as the most frequent instigators of the appearance of new pitches.

\section{Systematic method}

The method, which was developed by all artists who were working on division, was a comparison of new and old systems, the whole object and the divided one. Methods of the development of material were formed during the long period of 12-tone temperament practice. However, with the introduction of microtones and new equal or unequal temperaments, it became necessary to modernize the traditional ways, taking into account new intonation possibilities. This is the reason for the appearance of a systems comparison, melismatic development based on the smallest gradations of tone, the study of sound spectrum.

Example 3. - Edison Denisov, Piano trio (4th movement)t

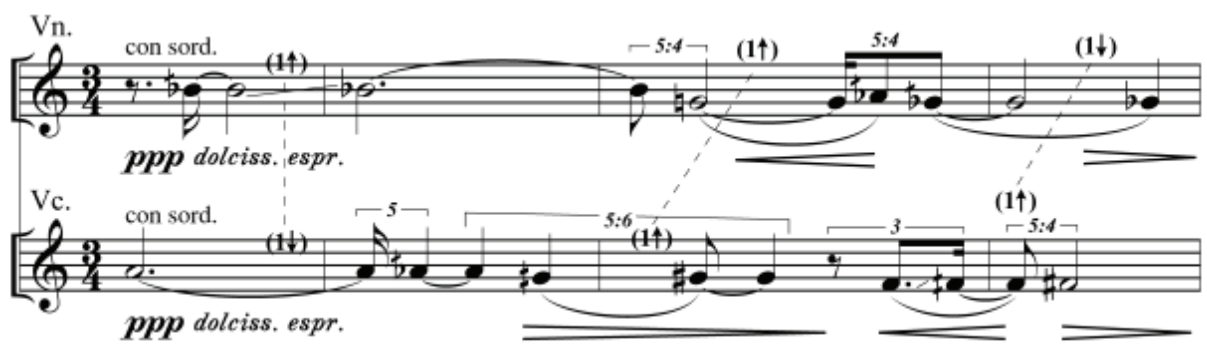


In previous example (ex. 3) one can trace the structure development. In this four-bar excerpt there is a model, which will be modernized later. A counterpoint of two lines is supposed to explore a tone as deeply as possible (through using quarter-tones). The violoncello descends, opposing the 'half-frozen' violin line, and only at the end, both lines proceed simultaneously, making confident microtonal steps.

\section{Computational method}

Mathematical techniques were used due to striving for the absolute accuracy and propriety of all experiments.

Composers' experiences in creating electronic music in Evgeny Murzin's studio at the Moscow Conservatory are marked by their experimental style. Schnittke confessed to the uselessness of his attempts to discover significant elements of pure intonation: this was just a "self- and music experiment" 16 . Schnittke thought about the blind alley, and reticence of a sound space in the overtone scale. In particular, he was dismayed by the impossibility of modulation to another mode and necessity to belong to the general tone ('Having detected the first tone and listening attentively to its overtones, our ear cannot imagine any more tones. It is satisfied with the first tone and microcosm [my italics - L. A.] of its overtones; thus the second tone becomes a mistake in relation to the first' ${ }^{17}$ ). Although at the time, some compositions were written for the ANS (standing for 'Andrey Nikolaevich Scriabin'), a device invented by Evgeny Murzin which was able to record different voices, polyphony and noises on its screen.

The range of this instrument was nearly 10 octaves, and at the same time the harmonic series was based on a 72-tone temperament. The inventor also planned to use the arrangement that could allow working with an octave divided into 144 intervals, or even 216. Examples: Schnittke's Stream, Denisov's Bird singing, Vivente - non vivente by Gubaidulina. It is important to mention this, because the inception of spaceflights (in 1961 the first artificial satellite Vostok was launched) and conquering 'new horizons' created an image in the minds of the 1960s' generations that microtonal music was, above all, associated with the infinity of the universe, which no human being could control. And it is no coincidence that the predominant film plots at that time (Toward the Cosmos, Solaris) and their musical scores were supported by the ANS and non-tempered system.

${ }_{16}$ M. Tarakanov (ed.), Problemy traditsij i novatorstva v sovremennoj muzyke, Moscow, Sovetskij kompozitor, 1982, 104-7.

17 Ibid., 106. 
Evgeny Murzin could be compared with Arseny Avraamov, one of the leaders of the first avant-garde radical wave. Both preferred the 72-tone temperament and both were fruitful inventors. In the 1960s, composers used different systems of temperament: compositions were written in the 17- and 29-tone systems (A. Ogolevets, 1941), the 21-tone system (P. Baranovsky, E. Utsevich, 1956), the 84-tone system (D. Guzenko, 1962), the 108-tone system (P. Meschaninov, 1980, "well-tempered sonority"). Georgy Rimsky-Korsakov and Ivan Wyschnegradky tested numerous systems, trying to discover the fundamental laws and principles enabling the construction of a new musical future.

Concerning the application tools of division, I would like to outline two general ways of using microtones. First of all, they were necessary for notating speech and folk music. The first attempts at employing the system occurred as early as 1864 , together with the construction of the first enharmonic piano in Russia, designed by Vladimir Odoevsky. He originally did not plan to use it for composing; instead, he wanted to prove that there are three scales - diatonic, chromatic and enharmonic.

In the 1920s, Arseny Avraamov in his dissertation declared that folk music might not survive if one did not use microtones to notate it. This precise method could help the next generation to reproduce songs as they were actually sung.

The 1960s were characterized by a growing interest for rearrangements of folk songs. For example, Boris Tischenko used folk songs in his compositions Yaroslavna, Severnie etudy [Nordic etudes] and in many other works. Nordic etudes were published in 1968. This is music written for a documentary film about Solovki. In this suite, there is a story told by an old woman, Yliana, who is singing songs, finishing them abruptly. In the final piece, called Veselie igrushki $\{$ Merry dolls $\}$ her song is played by the trombone in a very sarcastic way. The melody breaks constantly. The composer does not use microtonal notation, though he did employ markings signifying unequal temperament or imprecise pitch (x, $\nearrow \searrow$ ) (Ex. 4).

The other method of using microtones, which were popular at that time, was the method of additional pitches. Composers added microtones to enlarge the 12-tone system without aspiring to build a new tempered system or to base it on non-tempered possibilities. The same is apparent in Denisov's Sonata for saxophone and piano (1970), as an original dedication to Dmitry Shostakovich (he used a pitch sequence based on the composer's monogram), in which the second movement Lento is written for saxophone solo. He adhered to the classical form and material, and just interspersed microtones for sonoristic effect. 
Example 4.

Boris Tischenko, Severnie etudy. No. 9: Babka Yliana. Veselie igrushki
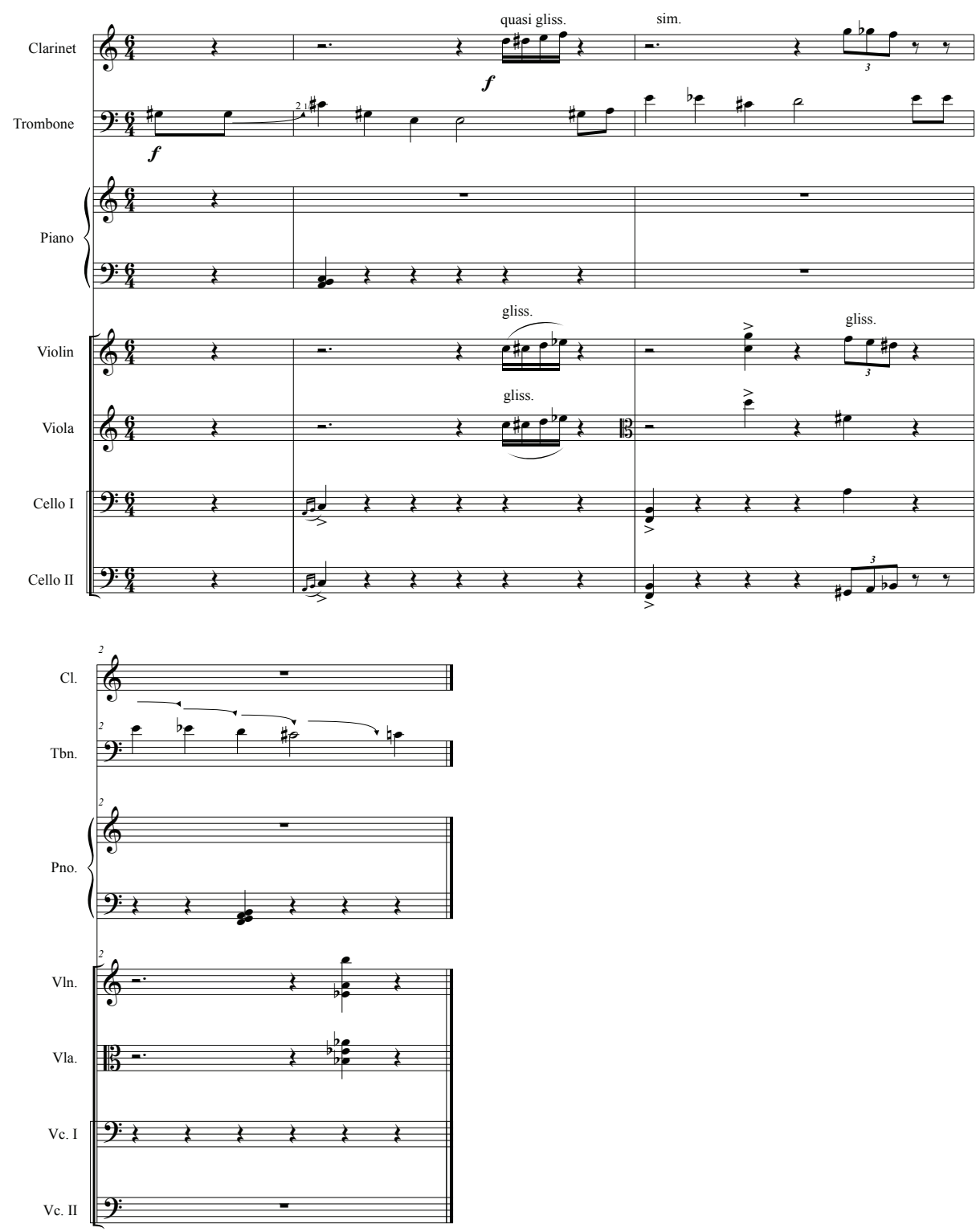


\section{Moscow vs. Leningrad}

In the history of Russian microtonal music one can observe a geographical feature: if leadership during the first avant-garde wave belonged completely to Petersburg-Petrograd-Leningrad, which became the nursery for the majority of novel ideas, the most radical experiments of the 1960s were happening in Moscow. Perhaps this could partly explain why in the mid-1950s, all of G. Rimsky-Korsakov's attempts to resume the Circle of quarter-tone music activity, and thereby bridge the gap in the dialogue of the two epochs, were utterly ignored. This time, the Circle was organized in an even more conservative place - the Leningrad Philharmonic Society, where the dissonant sounds of works by Hába, G. Rimsky-Korsakov himself and Wyschnegradsky were heard alongside of Mozart, Schubert and Rachmaninoff. This daring plan to initiate a revival of Soviet music sustained gradual defeat. In spite of serious illness, G. Rimsky-Korsakov continued his creative work, reconsidered previous works and thought about new ones. After a two-year break he got back to the quarter-tone music, pleased by the various responses he had received. In his flat he had a grand piano and a baby grand tuned a quarter-tone apart. On these instruments, he played his pieces with friends. Such musical evenings were attended by B. Burlakov (violoncello), musicologists A. Stupel, A. Finagin, V. Prokofiev, and, somewhat earlier, L. Nikolaev. Meetings in the Philharmonic Library were open and intended for non-professional music lovers. This stipulated a special type of conversation - free expression and bold initiative in preserving high science and musical potential. The last meeting in which G. Rimsky-Korsakov's participated took place in April 1962, when they celebrated the 25th anniversary of the Circle of chamber music lovers, pioneered by G. Rimsky-Korsakov and his friends. Later, even until his death in 1965, meetings took at his former flat, where Rimsky-Korsakov planned to present a paper on quarter-tone music and show recordings of his works. His dreams were not realized.

Having become aware of the fruitlessness of their efforts to combine two pitch spaces, the avant-garde composers of the 1910-1920s started to build a new model. Analysing the theoretical treatises of that time, one can draw a conclusion about the partial integration of the genre, structural, and modal principles of the 300-year system into the new one. At that point in the development of the latter, the achievements and work of theoreticians with the physical and mathematical parameters that laid out the deep mechanisms of the formation of pitch scales were successful. The strategies of composers of the 1960 s consisted evidently in the duplication of previous ideas. 


\section{Beyond Darmstadt}

Soon after its establishment in 1946, the International Music Institute in Darmstadt became widely known among musicians. By the early 1950s, it organized its own courses on particular types of music. There was simultaneous interest in dodecaphony, aleatoric, serial and electronic music ${ }^{18}$.

Microtonal music stood apart. Though it was still radical, innovative in terms of sound exploration, full of ideas about new systems, it was gradually ousted. There were two composers who competed with each other ever since they simultaneously developed a quarter-tone piano project in 1923. Ivan Wyschnegradsky and Alois Hába tried independently to introduce microtonal music to Darmstadt. They parted ways in the 1920 s, choosing completely different methods of composition. Wyschnegradsky always remained focused on the philosophy of music, also exploring spatial and polyphonic features; Hába was actually using twelve different 12 -tone and microtonal systems, experimenting with adopting new systems on newly discovered trends. Hába's temperament was closer to the avant-garde style, he was more successful at the Donaueschinger Musiktage in the 1920s, he was performed by the Amar Hindemith quartet, and he did a tour with his quarter-tone piano, etc. Wyschnegradsky was a typically marginal figure. He did not try to jump on the highest pedestal of appraisal; he waited for his musical thoughts to be understood by people.

Wolfgang Steincke was the one who actually directed the musical tastes of the 1950s. Both Hába and Wyschnegradsky sent their proposals to Wolfgang Steincke, who was a director of the Darmstadt Ferienkurse.

Alois Hába was more successful, due to a recommendation by the director's friend and colleague, Andrea Golea. Hába's works were performed at the festival several times in the 1950s, and he was invited to give lectures there.

With Wyschnegradsky everything went slowly. Born Russian and living in France, he was never accepted by any of the French composition schools at the time, and remained apart from them all. He was much closer to the Russian musical spirit, and tried not to lose connections with his Russian musician-friends. This is probably why he eventually became a 'Russian composer' in exile in France.

In 1953, he asked Wolfgang Steincke about Darmstadt. ${ }^{19}$ He wondered whether the festival still existed. He did not know anything about its latest pro-

\footnotetext{
18 A detailed history of all Darmstadt styles is presented in a book: Gianmario Borio, Hermann Danuser (ed.), Im Zenit der Moderne. Die Internationalen Ferienkurse für Neue Musik Darmstadt 1946-1966. Geschichte und Dokumentation in vier Bänden. Freiburg im Breisgau, Rombach, 1997.

19 The correspondence between Ivan Wyschnegradsky and Wolfgang Steincke concerning his participation in Darmstadt Ferienkurse can be found in the Archive of IMD (Internationale Musikinstitute Darmstadt). I am very grateful to the IMD staff for their assistance.
} 
grams and suggested that quarter-tone music be introduced in the courses. "In this case I am in your disposal," concluded Wyschnegradsky. "My name as a pioneer of ultrachromatic music could not pass unnoticed by you. My quartertone compositions in general were performed in France and abroad, always with success." 20

Needless to say, he waited for two months before his letter was answered. Since he was busy with the preparation of courses, Steincke could neither answer properly nor invite him to participate in Darmstadt. However, his reply initiated their intense correspondence during 1953. Willing to help with performing Wyschnegradsky's music, he contacted the Nordwestdeutschen Radio in Köln where a chamber music festival was being organized at the time. The piece chosen for performance was the one most important for Wyschnegradsky himself. It was a symphony Thus spoke Zaratustra. The premiere was the turning-point of his entire creative career. Paris had heard it in 1937 with the pianists Monique Haas, Ina Marika, Edward Staempfli and Max Vredenburg. The symphony was then performed only once more, in 1947, in Brussels, by Marcelle Mercenier, Jenny Solheid, Sainpol Hou and Naum Sluszny.

Their correspondence continued with the matter of the composers' catalogue, which was initiated by the Darmstadt centre and was aimed at gathering information about those who were in any kind of contact with the institution. Steincke sent a request to Wyschnegradsky in December 1953. The main purpose of it was also an attempt to introduce the system to the public and to awaken the interest of German institutions in those compositions.

In addition, Steincke suggested contacting the German Hochschule, which was quite progressive-minded at the time. According to Steincke, Wyschnegradsky could give lectures on microtonal music and perform his works there. But not in the Darmstadt School.

So, what had actually happened?

By helping Wyschnegradsky with the German premiere of the symphony, Steincke acted from a sincere interest in his works. However, there was another side to these circumstances. He already had Alois Hába in mind and finally invited him in 1955 to join the courses. Wyschnegradsky, though, believed that the main reason for the director excluding his pieces from the program of courses were the obstacles in their performance. He wrote, that 'if there are no difficulties other than these, I must say that I also have other compositions, easier to play and probably even better suited for string instruments in the chamber style; particularly pieces for two pianos, for Ondes Martenot and two pianos, for viola

${ }^{20}$ A letter to Wolfgang Steinecke from 25.3.1953. 
and two pianos (Sonata in one movement) and so on; and, of course, for string quartet - all the pieces are written in quarter-tones (several in 1/6-tones for three pianos tuned one-sixth of a tone apart, and one composition that combines quarter-tones and sixth-tones). If you are interested,' - recapitulated Wyschnegradsky, 'I can write about it in more detail'. ${ }^{21}$

That was the last letter for three whole years. In the autumn of $1956 \mathrm{Wy}-$ schnegradsky renewed the correspondence, sending his latest work Polyphonie Spatiale. He insisted on the great difference between the symphony and this piece. He approached a new type of spatial music which was based on total harmony (maximum tone range and tone density), experiments with a so-called 'continuum' that differs by range and position in space, using a new type of spatial polyphony. Almost a year later, Wyschnegradsky received from Steincke a kind letter, saying with a feeling of regret - that he would try again to write to the Köln Radio Festival to organize a new performance for the composer, but this was never done.

All in all, Wyschnegradsky's assumptions concerning works that might interest the Darmstadt School failed. He tried to understand their tastes, but this proved futile. He was a composer with a different training, who did not fit in with the Darmstadt courses. By that time, the Darmstadt style had already been formed by choosing specific directions. Even Hába's works were performed only twice, and with the latter occasion, the history of microtonal music in Darmstadt ended.

\section{Conclusion. Why not concluded?}

The Darmstadt case is very illustrative. The rejection of microtonal music was logical, due to the development of other trends. Electronic music, which was on the rise, was much more advantageous even in discovering new sound worlds. The search for microsounds reflected on all kinds of musical language and soon became a fundamental part of it.

The well-known culturologist Arnold Toynbee formulated his own view about historical development as a change of cultural layer. According to his theory, the cooperation of composer in the 1960s' avant-garde had to become a high-powered converting system, which would adapt its early achievements. At this point, Toynbee's culturological strategy of challenges and its responses fails from the beginning. Thus, the response itself is too sluggish for the ideas, and its value is lower than that of the challenge. ${ }^{22}$

${ }^{21}$ A letter from Ivan Wyschnegradsky to Wolfgang Steincke from 1st October 1953.

22 Arnold J. Toynbee, A Study of History: Volume I. Oxford University Press, 1987, 570 p. 
Toynbee's core conception of historical development, though, might be examined. The first avant-garde composers, inventors, acousticians and physicists were working on a sound division. Their theories were much more successful than their musical results. During the 1900-1930s they had scientifically described the musical developments of the late $20^{\text {th }}$ century. For example, researchers at the State Institute of Musical Science (GIMN) in the mid-1920s were doing projects on 53-tone temperament, designing keyboard instruments, calculating its spectrum. This type of temperament was mostly used later, and the idea of using overtones as the ground of a piece was developed by spectralists.

How to evaluate, then, the generation of Russian composers during the second wave of the avant-garde? What mechanisms lay beneath the analysis of the often experimental works of the 1960-1970s? Moreover, why did they name it 'avant-garde'?

In attempting to prove the viability of non-ideological and anti-Soviet (meaning 'politically unreliable') music in Russia, the composers of the 19501970s sought to create absolute art without such impurities. Western art, which was primarily non-Soviet, was allowed into the country in extremely limited doses and was greedily taken up by hungry intellects. Their starting point was resistance to the political regime; the first avant-garde wave battled with the dominance of the classic-romantic tradition. The two generations had different enemies, and this is why the struggle and resistance had different results. 